\title{
Degradation of Aqueous 2,6-Dibromophenol Solution by In-Liquid Dielectric Barrier Microplasma
}

\author{
Shin-Ichiro Kojima1,2*, Keiko Katayama-Hirayama², Tetsuya Akitsu² \\ ${ }^{1}$ Department of Advanced Energy Engineering Science, Kyushu University, Kasuga, Japan \\ ${ }^{2}$ Interdisciplinary Graduate School of Medicine and Engineering, University of Yamanashi, Kofu, Japan \\ Email: *kojima@triam.kyushu-u.ac.jp, akitsu@yamanashi.ac.jp
}

Received 22 June 2016; accepted 8 August 2016; published 11 August 2016

Copyright (C) 2016 by authors and Scientific Research Publishing Inc.

This work is licensed under the Creative Commons Attribution International License (CC BY). http://creativecommons.org/licenses/by/4.0/

(c) (7) Open Access

\begin{abstract}
Degradation of 2,6-dibromophenol (2,6-DBP) in the aqueous solution was studied using dielectric barrier discharge in micro-bubbles. Experimental comparison of working gas Ar, $\mathrm{N}_{2}, \mathrm{O}_{2}$, and air showed that oxygen and air plasma efficiently decomposed 2,6-DBP to bromide ion, and inorganic carbon. The molecular orbital model was applied in the analysis of the degradation in electrophilic, nucleophilic, and radical reactions.
\end{abstract}

\section{Keywords}

\section{2,6-Dibromophenol, Atmospheric Pressure Plasma, Inductive Energy-Storage System}

\section{Introduction}

Today, myriad plastic materials are in use all around us: electronics boards, fire-retarding curtain, housings of household electrical appliance such as microwave ovens. Tetrabromobisphenol A (TBBPA) is a popular material and offers quality fire-retarding material, brominated poly-epoxy-phenolic resin, at low cost. Since 2007, TBBPA has been included in the OSPAR List of Chemicals for Priority Action, because anxiety about accumulation in the human body was expressed [1]. Many researchers have examined the fate of TBBPA in the environment, Ronen and Abeliovich, in 2000 [2]; Oeberg et al., in 2002 [3]; Erikson et al., in 2004 [4] ; Greeke et al., in 2006 [5]; Arbeli et al., in 2006 [6] and animals, Meerts et al., in 2000 [7]; Fujitani et al., in 2006 [8]; Zalko et al., 2006 in [9]; Antignac et al., in 2009 [10], and the evidence of environmental toxicity, WHO, in 1995 [11]; Hakk et al., in 2003 [12]; Ogunbayo et al., in 2008 [13]. 2,6-Dibromophenol (2,6-DBP) is also a flame retardant

\footnotetext{
${ }^{*}$ Corresponding author.
} 
in polymers and is detected as a degradation product in the slow sand filtration of TBBPA-contaminated water [14]. Similar bromine compound, 2,4,6-DBP is used as antiseptic, and 2,4-DBP shows estrogenic effect [15]. A permissible range by RoHS 2.0 in 2011 was 1000 ppm (0.1\%). After the research report by the World Health Organization (WHO) about the brominated phenols such as 2-BP, 2,6-DBP, and 2,4,6-DBP in drinking water in Canada, the maximum concentration were 42,60 , and $20 \mathrm{ng} / \mathrm{L}$, respectively, where as the normal value was less than $3 \mathrm{ng} / \mathrm{L}$ [16]. Residual material in the manufacturing industry is probably the cause of the ppb level contamination, and fire-retarding plastic materials scrap is building up in world-wide. 2,6-DBP compound hardly biodegrades, and accumulates in the environment [17]. 2,6-DBP is characterized by the odor of disinfectant at low threshold by the human sense of smell, as low as the ppt class. In this work, we aim at the remediation of water pollution, i.e., to remove 2,6-DBP using small coaxial dielectric barrier discharge with multiple working gases: $\mathrm{Ar}, \mathrm{O}_{2}$, and $\mathrm{N}_{2}$. The explanation for the degradation process of 2,6-DBP is studied by molecular orbital calculation.

\section{Materials and Methods}

\subsection{Experimental Equipment}

Figure 1 shows the experimental setup and the structure of a dielectric barrier discharge plasma operated in water and a solution of dibromophenol. Discharge plasma is excited in a quartz tube by high voltage pseud-sine wave excited by a voltage inverter (Logy Electric CO., Tokyo) between a tungsten-rhenium electrode, $0.65 \mathrm{~mm}$ in diameter, and the liquid surface inside the tube. This plasma source is capable of generating nonthermal plasma in multiple gas, inert gas and molecular gas: oxygen, nitrogen and an arbitrary mixture.

The ground electrode is surrounding a glass test tube, $35 \mathrm{~mm}$ internal diameter and 100 in length. This plasma source enables processing with air, and in the experimental part, air plasma exhibits efficient degradation of di-bromophenols. Gas flow was controlled with a piezo-actuator. The dielectric barrier discharge fits for the energy-saving operation of water remediation.

\subsection{Discharge Current, Voltage, Power}

The discharge characteristics of multiple gas was compared. The discharge voltage was measure with two high voltage probes, (Type-P-300, Tektronix, USA) and discharge current was measured with a current probe and amplifier (Type-TCP-312 and TCPA-300, Tektronix, USA) The Q-V Lissajous' figure was applied to measure the power dissipation in the dielectric barrier discharge. In this measurement, a capacitor was inserted in the discharge circuit. From the Q-V Lissajous' figure, discharge voltage $V_{a}$ is found as the difference between $V_{p}$ and $V_{c}$. The net charge is found from the capacitance $\mathrm{C}$ and the voltage across the capacitor. Dissipated energy $E$

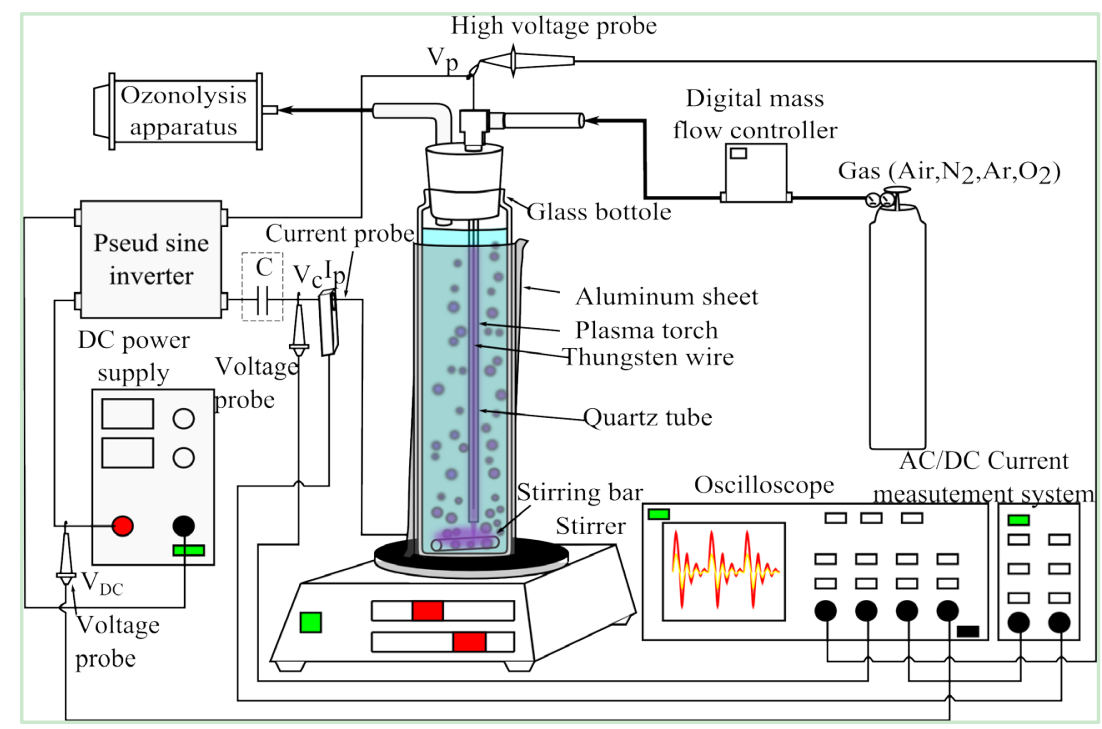

Figure 1. Dielectric barrier plasma decomposing 2,6-DBP in solution. 
is found per one cycle as in the following form. Electric power is found as the dissipated energy per cycle multiplied by the frequency.

Degradation of aqueous 2,6-dibromophenol solution by in-liquid dielectric barrier microplasma

$$
E=\int Q \mathrm{~d} V_{a}
$$

Table 1 summarizes the experimental result. The discharge voltage in Ar is relatively low and the discharge current indicated good stability. In the working gas containing oxygen, the discharge voltage was especially high and large noise was observed in the discharge current. The largest discharge power $12.67(\mathrm{~W})$ was observed in $\mathrm{O}_{2}$, and the degradation is completed in several minutes.

\subsection{Experimental Procedure}

In this experiment, the concentration of 2,6-DBP in the solution is $20 \mathrm{mg} / \mathrm{Little} .20 \mathrm{mg}$ of 2,6-DBP was measured and solved in alkaline solution then the solution was neutralized to $\mathrm{pH} 7$ with sulfuric acid. Individual trial was repeated for the solution of $100 \mathrm{~mL}$ in a test cylinder. The temporal evolution of the concentration of 2,6-DBP was determined by high-performance liquid chromatography (HPLC) with column: XBridge C18 (5 $\mathrm{mm} 4.6 \mathrm{~mm}$ i.d. $\times 250 \mathrm{~mm}$, Waters, USA); eluent: methanol/water $=70 / 30 \mathrm{pH} 4.0$ and adjusted with phosphoric acid; flow rate: $1 \mathrm{~mL} / \mathrm{min}$; detector: Hitachi L-2455 Photo Diode Array Detector; temperature: $40^{\circ} \mathrm{C}$, and UV detector (Hitachi L-4200) adjusted to $215 \mathrm{~nm}$.

Concentration of organic carbon was measured with TOC analyzer (TOC-L, Shimadzu, Kyoto, Japan). Concentration of anion $\left(\mathrm{Br}^{-}, \mathrm{NO}_{2}^{-}\right.$, and $\mathrm{NO}_{3}^{-}$) was measured with anion chromatography system (Dionex ICS1100). The concentration of anions was determined by ion chromatography with column: IC Pack Anion HR (Waters, USA) $(4.6 \mathrm{~mm}$ i.d. $\times 75 \mathrm{~mm})$; eluent: $0.75 \mathrm{mmol} / \mathrm{L}$ potassium biphthalate; flow rate: $1 \mathrm{~mL} / \mathrm{min}$; detector: HITACHI L-3700 Conductivity Detector; temperature: $40^{\circ} \mathrm{C}$. The concentration of dissolved organic carbon (DOC) was analyzed by a TOC analyzer (Shimadzu TOC Analyzer 5000, Japan).

The semiempirical molecular orbital calculation using a PM5 Hamiltonian was performed in MOPAC Version 6 with a CAChe package (Fujitsu Co., Tokyo, Japan).

\section{Results and Discussion}

\subsection{Candidate of Reactive Species in Plasma Discharge}

In the advanced oxidation processes (AOP) in weakly ionized oxygen, radicals such as $\mathrm{OH},{ }^{1} \mathrm{O}_{2}, \mathrm{O}, \mathrm{HO}_{2}, \mathrm{O}_{3}, \mathrm{O}_{2}^{-}$, and hydrogen radical $\mathrm{H}$ play important roles in the degradation of organic compounds to inorganic components: water and carbon dioxide gas. The reaction rate given by Sugimitsu is $\mathrm{OH}>>{ }^{1} \mathrm{O}_{2}>\mathrm{O}>>\mathrm{HO}_{2}>\mathrm{O}_{3}>>\mathrm{O}_{2}^{-}$[18]. The reactions with organic matter are concerned with active species in ozone and ultraviolet treatment in cleaning water. The generation processes of active species are different depending on the working gases. In this experiment, working gases Ar, oxygen, nitrogen and air are introduced to the discharge volume. A solution is given energy by working gas made into plasma in water, and it is formed active species such as $\mathrm{OH}, \mathrm{H}$ and hydrated electron form in the solution [19]. For example, (1)-(3) are relatively slow reactions and incapable of forming $\mathrm{OH}$ radicals.

$$
\begin{aligned}
& \mathrm{H}_{2} \mathrm{O} \rightarrow \mathrm{OH}+\mathrm{H} \\
& 2 \mathrm{e}_{\mathrm{aq}} \rightarrow \mathrm{H}_{2}+2 \mathrm{OH}^{-} \\
& \mathrm{H}_{2} \mathrm{O} \rightarrow \mathrm{H}^{+}+\mathrm{e}_{\mathrm{aq}}+\mathrm{OH}
\end{aligned}
$$

In oxygen and mixtures, ozone molecule and hydroxyl radical are generated by the following reactions: (4)-(6).

$$
\begin{aligned}
& \mathrm{e}+\mathrm{O}_{2} \rightarrow 2 \mathrm{O}+\mathrm{e} \\
& \mathrm{O}+\mathrm{O}_{2} \rightarrow \mathrm{O}_{3} \\
& \mathrm{O}_{3}+\mathrm{H}_{2} \mathrm{O} \rightarrow \mathrm{O}_{2}+2 \mathrm{OH}
\end{aligned}
$$


Table 1. Discharge characteristics in various working gas.

\begin{tabular}{cccccc}
\hline \multirow{2}{*}{ Object } & Unit & \multicolumn{3}{c}{ Working gas } \\
\cline { 3 - 6 } & & $\mathrm{N}_{2}$ & $\mathrm{Ar}$ & Air & $\mathrm{O}_{2}$ \\
\hline \multirow{2}{*}{ Applied voltage $V_{p}$} & Frequency $(\mathrm{kHz})$ & 16.94 & 16.69 & 16.88 & 16.91 \\
& Peak to peak voltage $(\mathrm{kV})$ & 7.76 & 4.32 & 7.84 & 7.68 \\
Discharge current $I_{p}$ & Peak to peak current (mA) & 480 & 560 & 920 & 3240 \\
Discharge power $P$ & $(\mathrm{~W})$ & 6.94 & 4.90 & 10.26 & 12.67 \\
\hline
\end{tabular}

Generally in oxygen discharges, hydroxyl radicals contribute to the advanced oxidation. The production of this species is, for example, the dissociation reaction of hydrogen peroxide. In the oxygen discharges, hydrogen peroxide is produced through (7)-(9), then hydroxyl radical is produced through the reaction of hydrogen peroxide dissociated hydrogen atom and hydrated electron, $\mathrm{e}_{\mathrm{aq}}[19]$. Thus, oxygen plasma exhibits high reactivity against organic compounds through the advanced oxidation reaction by hydroxyl radical, either by ozone or hydrogen peroxide.

$$
\begin{aligned}
& \mathrm{O}^{-}+\mathrm{O}_{3}^{-} \rightarrow 2 \mathrm{O}_{2}^{-} \\
& \mathrm{H}+\mathrm{O}_{2}^{-} \rightarrow \mathrm{HO}_{2}^{-} \\
& \mathrm{HO}_{2}^{-}+\mathrm{H}_{2} \mathrm{O} \rightarrow \mathrm{H}_{2} \mathrm{O}_{2}+\mathrm{OH}^{-} \\
& \mathrm{O}^{-}+\mathrm{H}_{2} \mathrm{O} \rightarrow \mathrm{OH}^{-}+\mathrm{OH} \\
& \mathrm{H}+\mathrm{H}_{2} \mathrm{O}_{2} \rightarrow \mathrm{H}_{2} \mathrm{O}+\mathrm{OH} \\
& \mathrm{e}_{\mathrm{aq}}+\mathrm{H}_{2} \mathrm{O}_{2} \rightarrow \mathrm{OH}^{-}+\mathrm{OH}
\end{aligned}
$$

\subsection{Degradation of 2,6-DBP}

Figure 2 shows the temporal evolution of the residual concentration of 2,6-DBP. Efficient plasma degradation is observed in all working conditions. Apparently, the degradation process in nitrogen and Ar discharge is different from the rapid degradation by oxygen and air. Figure 3 shows and experimental comparison of the degradation rate of 2,6-DBP. The degradation rate coefficient is determined ask. $C_{0}$ is the initial concentration of 2,6-DBP $(\mathrm{mg} / \mathrm{L}), C_{t}$ is the concentration after the elapsed time $t(\mathrm{~min}$.$) . Table 2$ shows the residual concentration of 2,6DBP 60 minutes after the plasma degradation. In the oxygen and air discharge case, the $100 \%$ and $99.73 \%$ of degradation rate is achieved. It should be noted that in the latter case, $98.78 \%$ is achieved in 5 minutes.

The reaction rate is constant in the initial stage of the degradation reaction, then apparent slowdown occurs by the secondary reaction. Table 3 summarizes the reaction rate in the initial stage. The order of the degradation rate shows $\mathrm{O}_{2}>\mathrm{Air}>\mathrm{Ar}>\mathrm{N}_{2}$. The reaction rate is calculated from the experimental result of the first 5 minutes.

$$
\begin{gathered}
\text { Degradation ratio }=\frac{\text { concentration }(2,6-\mathrm{DBP})-\text { concentration }(2,6-\mathrm{DBP})_{t=0}}{\text { Density }(2,6-\mathrm{DBP})_{t=0}} \times 100 \\
\ln \left(\frac{C_{t}}{C_{0}}\right)=-k t
\end{gathered}
$$

In the case of oxygen, the reaction rate tends saturate in 5 minutes. This result suggests the effect of competing production of the byproduct.

\subsection{Degradation of Organic Carbon, TOC Density}

Total Organic Carbon (TOC) concentration is an index showing the concentration of the organic compound in 


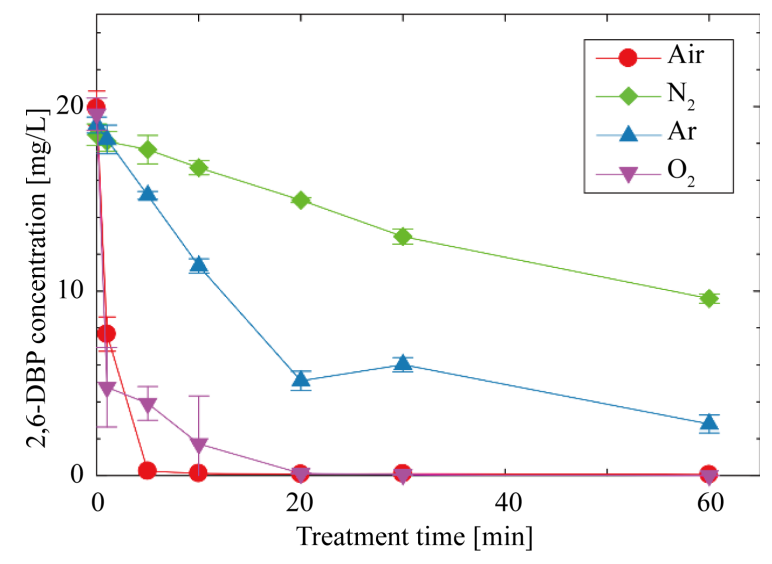

Figure 2. Degradation of 2,6-DBP in aqueous solutions.

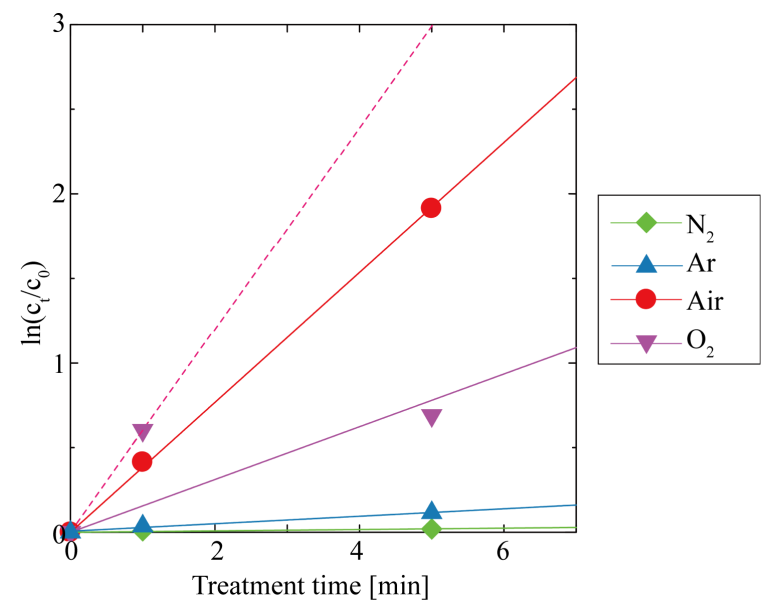

Figure 3. Degradation of 2,6-DBP: Reaction rate.

Table 2. Comparison of the degradation rate of 2,6-DBP in 60 minutes.

\begin{tabular}{cccc}
\hline Working gas & 2,6-DBP degradation [\%] & TOC degradation [\%] & Production of $\mathrm{Br}^{-}[\%]$ \\
\hline $\mathrm{N}_{2}$ & 48.06 & 48.49 & 30.74 \\
$\mathrm{Ar}$ & 85.87 & 76.25 & 77.27 \\
$\mathrm{Air}$ & 99.73 & 72.82 & 10.30 \\
$\mathrm{O}_{2}$ & 100.00 & 100.00 & 24.96 \\
\hline
\end{tabular}

Table 3. Comparison of the degradation rate of 2,6-DBP in the initial stage.

\begin{tabular}{ccccc}
\hline Working gas & $\mathrm{N}_{2}$ & $\mathrm{Ar}$ & Air & $\mathrm{O}_{2}$ \\
\hline Reaction rate $k\left(\mathrm{~min}^{-1}\right)$ & 0.0041 & 0.0235 & 0.3839 & $(0.6029)$ \\
\hline
\end{tabular}

the water pollution control. In this experiment, TOC was evaluated as a measure for the dissociation of 2,6-DBP. Figure 4 shows the temporal evolution of the TOC concentration. TOC concentration decreased in all workinggases. The reactivity of oxygen gas was high and the decrease in TOC was completed within 20 minutes, with time constant of 7 to 8 minutes. In air and nitrogen cases, TOC concentration is approximately constant after 30 minutes of treatment. This result suggests that the dissociation balances with the production in some kind of chemical equilibrium. 


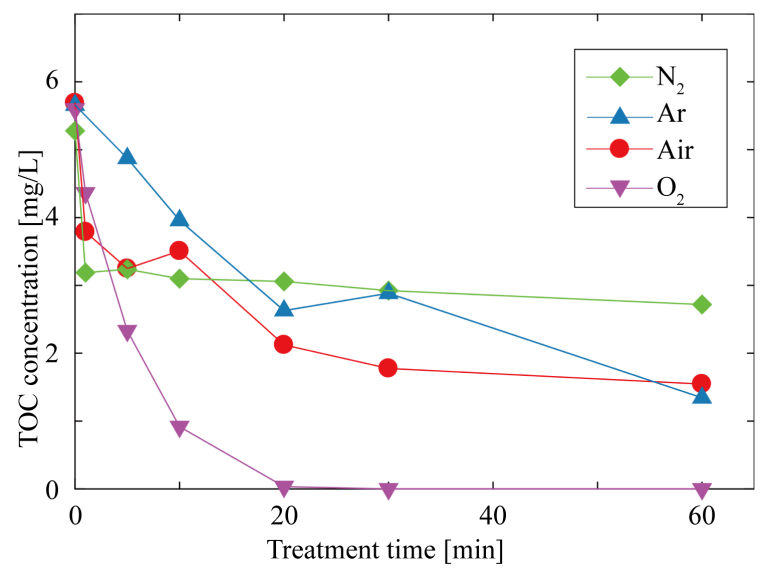

Figure 4. Total Organic Carbon (TOC) concentration profile during plasma radiation.

\subsection{Concentration of Ionic Bi-Product}

In the measurement of anion product, $\mathrm{BrO}_{3}^{-}$anion was identified in $\mathrm{Ar}, \mathrm{O}_{2}, \mathrm{~N}_{2}$, and $\mathrm{NO}_{3}^{-}$was identified only in the case of air plasma. Figure 5(a) shows the concentration of $\mathrm{Br}^{-}$anion. $\mathrm{Br}^{-}$is produced from 2,6-DBP, the dissociation from the phenol-benzene ring. Depending on the working gas, one can find two types of temporal evolution. The first pattern is the initial increase and decrease in $\mathrm{Br}^{-}$concentration, as in oxygen and air plasma. The second pattern is the continuous increase in the concentration. The production of $\mathrm{Br}^{-}$anion is $79.71 \%$ after 1 minute in oxygen plasma processing and $71.30 \%$ after 5 minutes in air plasma. Almost all $\mathrm{Br}^{-}$anion is produced in the first several minutes of the plasma processing. The decrease in $\mathrm{Br}^{-}$anion intensity suggests that $\mathrm{Br}^{-}$ is consumed in the production of stable compound in the oxygen and air discharge case. In these cases, a possible explanation is the conversion to $\mathrm{BrO}_{3}^{-}$anion by the advanced oxidation of $\mathrm{Br}^{-}$anion [20] [21]. Figure 5(b) shows the concentration of $\mathrm{BrO}_{3}^{-}$anion, as function of the processing time. In the oxygen discharge case, the concentration of $\mathrm{BrO}_{3}^{-}$anion increases. In contrast, in the air discharge, the concentration of $\mathrm{BrO}_{3}^{-}$anion shows a maximum in the initial stage. In the air plasma discharge, one can find that the concentration of $\mathrm{BrO}_{3}^{-}$ anion shows a maximum at 1 minute after the beginning of the processing, then starts to decrease, and no $\mathrm{BrO}_{3}^{-}$ anion can be observed in 20 minutes. In inert gases, $\mathrm{BrO}_{3}^{-}$can be observed in 60 minutes in the $\mathrm{Ar}$ case. No $\mathrm{BrO}_{3}^{-}$intensity was observed in the nitrogen plasma case.

The advanced oxidation process of $\mathrm{Br}^{-}$anion is shown in Figure 6, following the proposal by Urs von Gunten [20] [21]. Advanced oxidation by hydroxyl radical and ozone produces $\mathrm{BrO}_{3}^{-}$, through the production of $\mathrm{HOBr}$ and $\mathrm{BrO}^{-}$anion by ozone and BrO by hydroxyl radical. In the air plasma case in Figure 7, initial increase in the density of $\mathrm{Br}^{-}$and $\mathrm{BrO}_{3}^{-}$is interrupted by some competing reaction and $\mathrm{BrO}_{3}^{-}$disappears in 20 minutes after the start. The oxidation process of nitrogen produces $\mathrm{NO}_{3}^{-}$anion, then $\mathrm{NO}_{3}^{-}$anion react with $\mathrm{Br}^{-}$anion and produces stable compound $\mathrm{Br}_{2}$. This reaction tends to decrease in $\mathrm{Br}^{-}$and $\mathrm{BrO}_{3}^{-}$density.

$$
\begin{aligned}
& \mathrm{O}_{3}+\mathrm{NO}_{2}^{-} \rightarrow \mathrm{O}_{2}+\mathrm{NO}_{3}^{-} \\
& \mathrm{NO}_{3}^{-}+2 \mathrm{Br}^{-}+3 \mathrm{H}^{+} \rightarrow \mathrm{Br}_{2}+\mathrm{HNO}_{2}+\mathrm{H}_{2} \mathrm{O}
\end{aligned}
$$

Identification and estimation of the resultant products remain to be examined for detailed verification of 2,6-DBP degradation.

\subsection{Calculation of Radical, Nucleophilic, and Electrophilic Frontier Density of 2,6-DBP}

To learn the mechanism of the advanced oxidation, we used the molecular orbital theory (CAChe, Fujitsu CO., Japan). Figure 8 shows contour plots of the radical reaction, electrophilic, and nucleophilic frontier density of 2,6-DBP. Electrophilic frontier density reveals reactive sites based on the electron distribution of active orbitals near HOMO (highest occupied molecular orbital) Radical reaction and electrophilic reaction has small area of 0.002 to 0.003 in the central area of its molecule. Molecular orbital calculation of 2,6-DBP shows that degrada- 


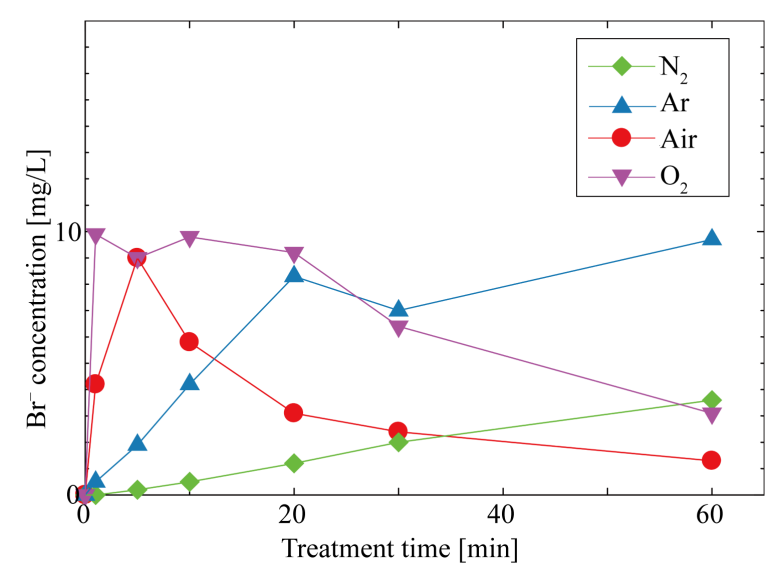

(a)

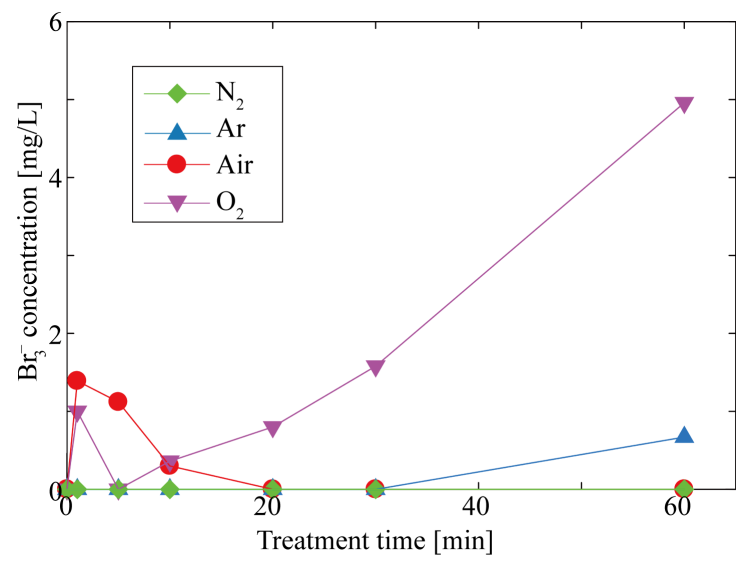

(b)

Figure 5. Concentration of by-product. (a) Density of $\mathrm{Br}^{-}$anion; (b) Concentration density of $\mathrm{BrO}_{3}^{-}$.

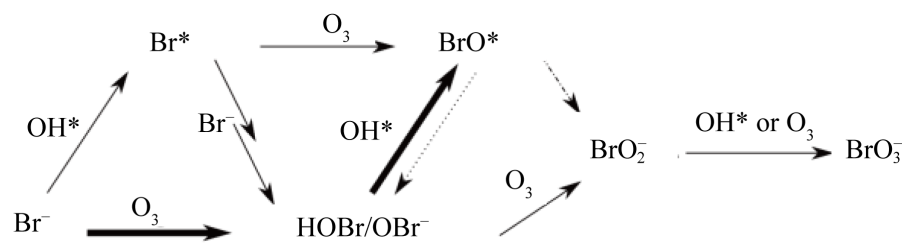

Figure 6. Production of $\mathrm{Br}^{-}$and $\mathrm{BrO}_{3}^{-}$in the advanced oxidation process [8] [9].

tion is partly explained on the basis of electrophilic frontier density, where hydrogen radical contributes to various reactions. Nucleophilic frontier density is a measure of the susceptibility to a nucleophilic attack and reactive sites based on the electron distribution of active orbitals near the LUMO (lowest unoccupied molecular orbital). The counter plot of nucleophilic frontier density is at the same level around the main ring. Anion radicals such as $\mathrm{OH}^{-}$does not contribute to the degradation. Radical reaction and the nucleophilic reaction has round area of 0.003 to 0.005 at the $\mathrm{Br}$ site.

Figure 8(b) shows the radical reaction frontier density. This result presents small area of highest susceptibility to radical reactions on the top of $\mathrm{Br}$ atoms of 2,6-DBP, $\mathrm{Br}$ atom $\mathrm{Br}(8)$ on the right and on the left $\mathrm{Br}$ atom $\mathrm{Br}(9)$. Br site of 2,6-DBP has high susceptibility to nucleophilic radicals. Figure 8(c) shows nucleophilic frontier density, where the highest susceptibility is localized on the top of $\operatorname{Br}(9)$ on the left and $\operatorname{Br}(10)$ on the right. Hydroxyl radicals in $\mathrm{OH}$ radical or $\mathrm{OH}$ ion attack these sites and contribute to the detachment of $\mathrm{Br}$ atoms. Figure $\mathbf{8}$ (d) shows the electrophilic frontier density, where the highest susceptibility site is localized in the middle 


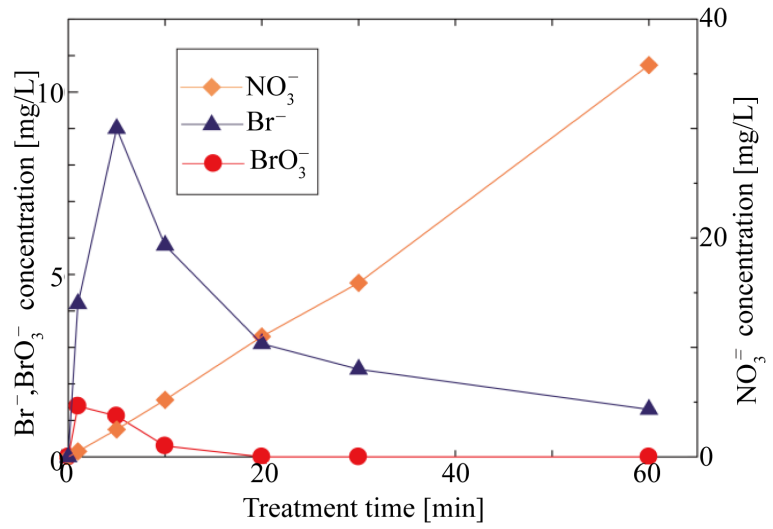

Figure 7. Anionic product in the case of air plasma.

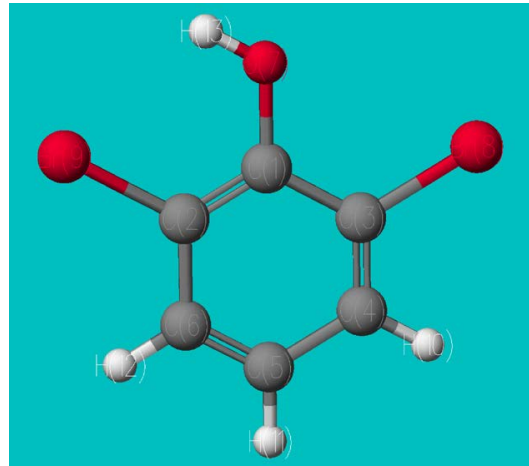

(a)

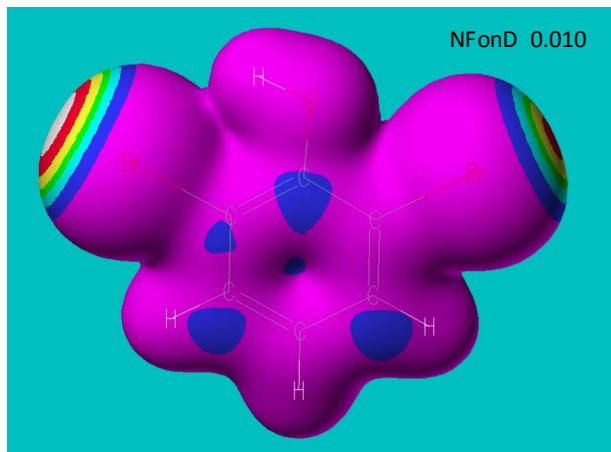

(c)
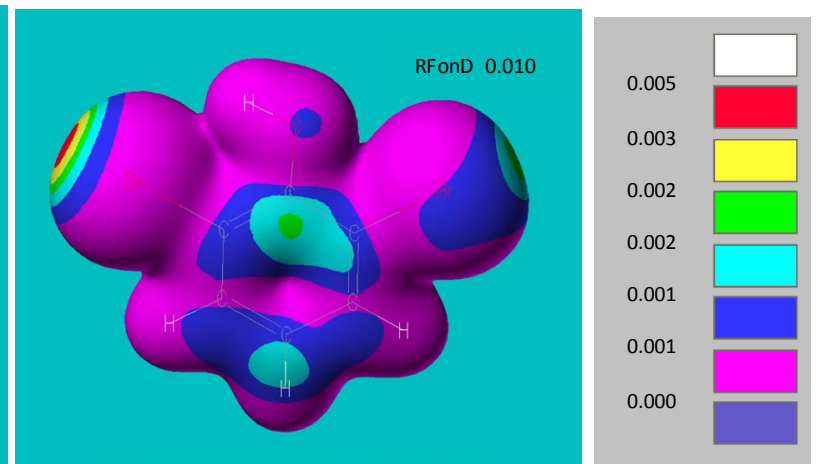

(b)

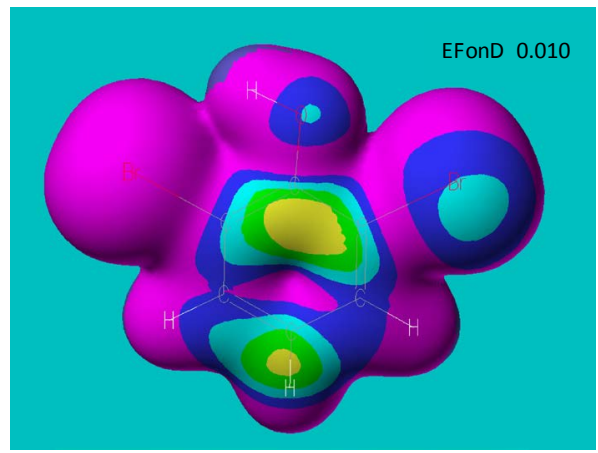

(d)

Figure 8. Radical, nucleophilic and electrophilic active frontier density. (a) Molecular orbital model of 2,6-DBP; (b) Radical reaction susceptibility; (c) Nucleophilic frontier density; (d) Electrophilic frontier density.

of the benzene ring, where attacked by hydrogen ion $\mathrm{H}^{+}$contributes to the collapse of the benzene ring. Thus, the degradation of 2,6-DBP is reached by the combination of the radical, nucleophilic and electrophilic reaction. This mechanism can explain the efficient degradation of 2,6-DBP by oxygen and air plasma injection.

\subsection{Profile of $\mathrm{pH}$}

Table 4 shows the temporal evolution of $\mathrm{pH}$ in all settings. In the initial liquid sample, the concentration density of 2,6-DBP was $20 \mathrm{mg} / \mathrm{L}$ and $\mathrm{pH}$ was adjusted to 7.0. In all experiments, the decrease in $\mathrm{pH}$ was observed in the initial stage. In the air plasma process, the $\mathrm{pH}$ decrease with the degradation of 2,6-DBP may becaused by the 
Table 4. Measurement of $\mathrm{pH}$ in the plasma degradation of 2,6-DBP.

\begin{tabular}{ccccc}
\hline & \multicolumn{3}{c}{ Working gas } \\
Processing time (min.) & $\mathrm{N}_{2}$ & $\mathrm{Ar}$ & $\mathrm{Air}$ & $\mathrm{O}_{2}$ \\
\cline { 2 - 5 } & 6.47 & 5.91 & 3.75 & 4.35 \\
5 & 6.42 & 4.66 & 3.55 & 4.40 \\
10 & 6.36 & 4.15 & 3.29 & 4.51 \\
30 & 6.28 & 4.61 & 3.18 & 5.05 \\
60 & 5.99 & 4.05 & 2.87 & 6.04 \\
\hline
\end{tabular}

formation of $\mathrm{NO}_{3}^{-}$as well as the consume of $\mathrm{OH}^{-}$in the degradation process.

\section{Conclusion}

In this study, we traced the degradation of aqueous solution of 2,6-DBP by a aqueous glow discharge to inorganic carbon in a matter of several minutes. Although the identification and toxicity assessment of the resultant products remain to be examined for detailed verification of 2,6-DBP degradation, this process is an alternative choice in the degradation of TBBPA. In the fire burn destruction of such fire-retarding products, human toxicity such as the dioxin is a great concern. In the degradation of the solution, the ozone injection and the ultra violet radiation are compared. The degradation using the advanced oxidation, such as ozone injection, is employed in various water plants for sewage treatment. These reaction attacks the radical and nucleophilicreaction site. The electrophilic reaction shows higher activities in the degradation of the benzene ring, as shown in the present work.

The characteristic of decomposition of 2,6-DBP is different for molecules, ions and radicals formed in plasma of multiple working gases. The reaction rate of decomposition reaction is $\mathrm{O}_{2}>\mathrm{Air}>\mathrm{Ar}>\mathrm{N}_{2}$. The treatment $\mathrm{O}_{2}$ as the working gas has the greatest reaction rate, shown after 60 minutes. $\mathrm{Br}^{-}$and $\mathrm{BrO}_{3}^{-}$anions are observed as ionic products in decomposition of 2,6-DBP. It is thought $\mathrm{Br}^{-}$is formed by radical reaction and nucleophilic reaction, and $\mathrm{BrO}_{3}^{-}$is formed by peroxidation. $\mathrm{NO}_{3}^{-}$anion is observed also, and it is formed from chemical combination of nitrogen and oxide in air as the working gas. Radical reaction, nucleophilic and electrophilic reaction is happen at same time in dissociation process of 2,6-DBP. In the first stage, $\mathrm{Br}^{-}$anion is formed by components such as $\mathrm{OH}$ and $\mathrm{OH}^{-}$anion predominantly from radical and nucleophilic reaction. Finally, the benzene ring is broken by components such as $\mathrm{H}_{\text {and }} \mathrm{H}^{+}$ion from electrophilic reaction. It was thought that from measurements of $\mathrm{pH}$ by plasma of $\mathrm{O}_{2}$ as working gas, the plasma that shows the best decomposition characteristic is plasma of $\mathrm{O}_{2}$ as the working gas, because it is able to form many active species. For $\mathrm{BrO}_{3}^{-}$anion toxicity, more investigations are needed to utilize as water purification.

\section{Acknowledgements}

The author express thanks to Dr. Katsuhisa Kitano of Osaka University for the stimulation of this discussion.

\section{References}

[1] Grros, R., Bunke, D., Gensch, C.O., Zangi, S. and Manhart, A. (2008) Study on Hazardous Substances in Electrical and Electronic Equipment, Not Regulated by the RoHS Directive. Öko-Institut e.V., No.070307/2007/476836/MAR/G4, 47-61.

[2] Ronen, Z. and Abeliovich, A. (2000) Anaerobic-Aerobic Process for Microbial Degradation of Tetrabromobisphenol A. Applied and Environmental Microbiology, 66, 2372-2377. http://dx.doi.org/10.1128/AEM.66.6.2372-2377.2000

[3] Oeberg, K., Warman, K. and Oeberg, T. (2002) Distribution and Levels of Brominated Flame Retardants in Sewage Sludge. Chemosphere, 48, 805-809. http://dx.doi.org/10.1016/S0045-6535(02)00113-3

[4] Erikson, J., Rahm, S., Green, N., Bergman, A. and Jakobson, E. (2004) Photochemical Transformations of Tetrabromobis-Phenol A and Related Phenols in Water. Chemosphere, 54, 117-226. http://dx.doi.org/10.1016/S0045-6535(03)00704-5 
[5] Greeke, A.C., Giger, W., Hartmann, P., Heeb, N.V., Kohler, H.-P.E., Schmid, P., Zennegg, M. and Kohler, M. (2006) Anaerobic Degradation of Brominated Flame Retardants in Sewage Sludge. Chemosphere, 64, 311-317. http://dx.doi.org/10.1016/j.chemosphere.2005.12.016

[6] Arbeli, Z., Ronen, Z. and Diaz-Baez, M.C. (2006) Reductive Dehalogenation of Tetrabromobisphenol-A by Sediment from a Contaminated Ephemeral Streamed and an Enrichment Culture. Chemosphere, 64, 1472-1478. http://dx.doi.org/10.1093/toxsci/56.1.95

[7] Meerts, I.A., van Zenden, J.J., Luijks, E.A.C., van Leeuwen-Bol, I., Marsh, G., Jakobson, E., Bergman, A. and Brouwer, A. (2000) Potent Competitive Interactions of Some Brominated Flame Retardants and Related Compounds with Human Transthyration in Vitro. Toxicological Science, 56, 95-104. http://dx.doi.org/10.1093/toxsci/56.1.95

[8] Fujitani, T., Toda, Y., Takahashi, H., Yano, N., Ando, H., Kubo, Y., Yuzawa, K., Nagasawa, A., Ogata, A. and Kamimura, H. (2006) Placental Transfer of Tetrabromobisphenol A and Excretion to Milk in Mice. Annual Report of Tokyo Metropolitan Institute of Public Health, 57, 361-365.

[9] Zalko, D., Prouillac, C., Riu, A., Perde, E., Dolo, L., Jouanin, I., Canlet, C., Debrauwer, L. and Cravedi, J.-P. (2006) Bio-Transformation of the Flame Retardant Terrabromo-Bisphenol A by Human and Rat Sub-Cellular Liver Fractions. Chemosphere, 64, 318-327. http://dx.doi.org/10.1016/j.chemosphere.2005.12.053

[10] Antignac, J.-P., Cariou, R., Zalko, D., Berrebi, A., Cravedi, J.-P., Maume, D., Marchand, P., Monteau, F., Riu, A., Andre, F. and Le Bizec, B. (2009) Exposure Assessment of French Women and Their Newborn to Brominated Flame Retardants: Determination of Tri- to Deca-Polybromodiphenylethers (PBDE) in Maternal Adipose Tissue, Serum, Breast Milk and Cord Serum. Environmental Pollution, 157, 164-173. http://dx.doi.org/10.1016/j.envpol.2008.07.008

[11] WHO (World Health Organization) (1995) Tetrabromobisphenol A and Derivatives. Environmental Health Criteria, 172, 25-47.

[12] Hakk, H. and Letche, R.J. (2003) Metabolism in the Toxicokinetics and Fate of Brominated Flame Retardants-A Review. Environment International, 29, 801-828. http://dx.doi.org/10.1016/S0160-4120(03)00109-0

[13] Ogunbayo, O.A., Lai, P.F., Connolly, T.J. and Michelangeli, F. (2008) Tetrabromobisphenol A (TBBPA), Induces Cell Death in TM4 Sertoli Cells by Modulating $\mathrm{Ca}^{2+}$ Transport Proteins and Causing Disregulation of $\mathrm{Ca}^{2+}$ Homeostasis. Toxicology in Vitro, 22, 943-952. http://dx.doi.org/10.1016/j.tiv.2008.01.015

[14] Katayama-Hirayama, K., Suzuki, A., Mukaiyama, S., Hirayma, K. and Akitsu, T. (2010) Removal of Tetrabromobisphenol A by Slow-Sand Filtration and a High-Performance UV Lamp System. Sustainable Environment Research, 20, 221-225.

[15] Olsen, C.M., Meussuen-Eltholm, E.T.M., Holme, J.A. and Hongslo, J.K. (2002) Brominated Phenols: Characterization of Estrogen-Like Activity in the Human Breast Cancer Cell-Line MCF-7. Toxicology Letters, 129, 55-63.

[16] World Health Organization (2005) 2,4,6-Tribromophenol and Other Simple Brominated Phenols. Concise International Chemical Assessment Document, World Health Organization, Geneva, 66.

[17] Katayama-Hirayama, K., Toda, N., Tauchi, A., Fujioka, A., Akitsu, T., Kaneko, H. and Hirayama, K. (2014) Degradation of Dibromophenols by UV Irradiation. Journal of Environmental Sciences, 26, 1284-1288.

[18] Sugimitsu, H. (1995) Ozone. Tokuyama University, Institute for General Research, Yamaguchi. (In Japanese)

[19] Joshi, A.A., Locke, B.R., Arce, P. and Finney, W.C. (1995) Formation of Hydroxyl Radicals, Hydrogen Peroxide and Aqueous Electrons by Pulsed Streamer Corona Discharge in Aqueous Solution. Journal of Hazardous Materials, 41, 330. http://dx.doi.org/10.1016/0304-3894(94)00099-3

[20] Von Gunten, U. and Higné, J. (1994) Bromate Formation during Ozonation of Bromide-Containing Waters: Interaction of Ozone and Hydroxyl Radical Reactions. Environmental Science \& Technology, 28, 1234-1242. http://dx.doi.org/10.1021/es00056a009

[21] Von Gunten, U. (2003) Ozonation of Drinking Water: Part II. Disinfection and By-Product Formation in Presence of Bromide, Iodide or Chlorine. Water Research, 37, 1469-1487. http://dx.doi.org/10.1016/S0043-1354(02)00458-X 


\section{Submit or recommend next manuscript to SCIRP and we will provide best service for you:}

Accepting pre-submission inquiries through Email, Facebook, LinkedIn, Twitter, etc.

A wide selection of journals (inclusive of 9 subjects, more than 200 journals)

Providing 24-hour high-quality service

User-friendly online submission system

Fair and swift peer-review system

Efficient typesetting and proofreading procedure

Display of the result of downloads and visits, as well as the number of cited articles

Maximum dissemination of your research work

Submit your manuscript at: http://papersubmission.scirp.org/ 